DOI: https://doi.org/10.17816/ecogen35203

\title{
APPLICATION OF SMALL RNAS FOR PLANT PROTECTION
}

(c) P.Ya. Tretiakova ${ }^{1}$, A.A. Soloviev ${ }^{2}$

${ }^{1}$ Russian State Agrarian University - Moscow Timiryazev Agricultural Academy, Moscow, Russia;

${ }^{2}$ All-Russia Research Institute of Agricultural Biotechnology, Moscow, Russia

Cite this article as: Tretiakova PYa, Soloviev AA. Application of small RNAs for plant protection. Ecological genetics. 2020;18(4):467-481. https://doi.org/10.17816/ecogen35203.

Received: 16.07.2020

Revised: 04.11 .2020

Accepted: 23.09.2020

Double-stranded small RNAs (dsRNA) perform various regulatory functions via RNA-interference. Additionally, they can be transported between various plant species and their pathogens and pests via extracellular vesicles, protecting RNA from nucleases. Plants secrete short dsRNA molecules to defend themselves against pathogens. The latter also use small RNAs when infecting crops. Some dsRNAs of pathogens are known as "ribonucleic effectors". Host-induced gene silencing (HIGS) was shown to be effective when breeding resistant varieties and analyzing plant-pathogen interactions. However, complexity of transgenesis and society fear of genetically modified products make HIGS application difficult. The appearance of a new strategy based on plant spraying with dsRNA gave a new perspective of plant protection. Currently such a strategy requires accurate studying as well as the development of efficient systems stably producing high-quality dsRNA.

Keywords: small RNA; silencing; HIGS; SIGS; RNA-interference; host; pathogen; vesicle; effector; dsRNA.

\section{МАЛЫЕ РНК В ЗАЩИТЕ РАСТЕНИЙ ОТ БОЛЕЗНЕЙ}

\section{(С) П.Я. Третьякова ${ }^{1}$, А.А. Соловьев ${ }^{2}$}

${ }^{1}$ Федеральное государственное бюджетное образовательное учреждение высшего образования «Российский государственный аграрный университет - MCXА им. К.А. Тимирязева», Москва;

${ }^{2}$ Федеральное государственное бюджетное научное учреждение

«Всероссийский научно-исследовательский институт сельскохозяйственной биотехнологии», Москва

Для цุитирования: Третьякова П.Я., Соловьев А.А. Малые РНК в защите растений от болезней // Экологическая генетика. - 2020. - Т. 18. № 4. - C. 467-481. https://doi.org/10.17816/ecogen35203.

Поступила: 16.07.2020

Одобрена: 04.11 .2020

Принята: 23.09.2020

\& Двухцепочечные малые РНК (дцРНК), включаясь в процесс РНК-интерференции, выполняют различные регуляторные функции во многих организмах. Были описаны случаи обмена малыми РНК между разными видами растений и поражающими их патогенами и вредителями посредством внеклеточных везикул (крошечных пузырьков), которые защищают их от действия нуклеаз. Растения секретируют двухцепочечные короткие молекулы РНК для борьбы с возбудителями заболеваний, а те, в свою очередь, используют малые РНК как инструмент, позволяющий им ослабить иммунитет хозяев. Некоторые дцРНК патогенов получили название «рибонуклеиновых эффекторов». Tехнология HIGS (host induced gene silencing - сайленсинг, индуцируемый растением-хозяином) показала свою эффективность в создании устойчивых сортов сельскохозяйственных культур и изучении различных патосистем. Однако использование ее ограничено из-за сложности создания трансгенных линий и запрета на их выращивание во многих странах. Распыление дцРНК по поверхности листьев, стеблей и соцветий растений может стать новым приемом контроля заболеваний, способным заменить использование пестицидов. На данный момент такая стратегия требует тщательного анализа и доработки, а также создания дешевых систем, стабильно синтезирующих дцРНК хорошего качества.

क्ष Ключевые слова: малые PHK; сайленсинг; HIGS; SIGS; PHK-интерференция; хозяин; патоген; везикулы; эффектор; дцРНК. 


\section{INTRODUCTION}

Plants have evolved to develop multi-layered defense mechanisms against pathogens and pests. In turn, pathogens have developed strategies to suppress the host immune response. The same microorganism interacts differently with several hosts, triggering a cascade of specific reactions. Some aspects of these interactions can be used to develop techniques that reduce virulence. Search for new ways to control pathogens will be critical for food safety as crop pathogens continue to evolve, resulting in their increased resistance to pesticides and host defense mechanisms.

Over the past decade, small RNAs have been found to regulate biological processes in eukaryotes, including growth, development, reproduction, and defense. Small RNAs can move both within the same organism and between interacting organisms (for example, from the host plant to the pathogen and vice versa) to silence gene expression.

\section{TYPES OF SMALL RNAS AND THEIR ROLES IN RNA INTERFERENCE}

Small RNAs include two large classes, namely micro and small interfering RNAs (miRNA and siRNA, respectively). MiRNA and siRNA are noncoding molecules, 20-30 bp in size, which are found in various organisms and are involved in many regulatory processes. SiRNAs are formed through the cutting of long double-stranded RNA (dsRNA), while miRNA has a hairpin structure formed from single-stranded RNA under the influence of RNase III ribonucleases. Being important mediators of RNA interference and components of the RNA-induced silencing complex (RISC), miRNA and siRNA can activate homologous mRNA cleavage [1].

The ribonuclease Dicer (RNase III family), which cuts large dsRNA molecules, and the RNA endonuclease Argonaute, which is a component of the RISC, are also involved in RNA interference.
How does Argonaute recognize the "very same" RNA? After inclusion in the RISC, the small, double-stranded RNA unwinds, the sense strand degrades, and the antisense strand is used as a "navigator," such that Argonaute, which has an RNA-binding site, cleaves the molecule that is complementary to the antisense strand [2-4]. Notably, RNA interference does not stop gene expression completely; decrease in expression depends on the concentration of small RNAs [5].

Although the formation of small RNAs is associated with the action of Dicer, several alternative pathways for the formation of small RNAs have been discovered, including the Dicer-independent mechanism. Such RNAs are called Dicer-independent siRNAs (disiRNAs) [6]. The many loci that form disiRNAs lead to the formation of overlapping fragments of sense and antisense transcripts $[7,8]$.

Several types of fungi, such as Saccharomyces cerevisiae Hansen and Ustilago maydis Corda, lack key components of the RNA-interference machinery [9, 10]. Erysiphe necator Schwein lacks an RNA-dependent RNA polymerase and DNA methylase, which suggests that this species lacks RNA interference [11]. Among fungi, a great diversity exists in the number of paralogs (homologues) of Argonaute and RNA-dependent RNA polymerase $[11,12]$. The presence of RNAinterference components has been described in plant pathogens such as $U$. maydis (not capable of RNA interference) and Ustilago hordei Lagerh. (capable of RNA interference) [10].

In some species of microscopic fungi, a class of small RNAs called microRNA-like RNAs (milRNAs) was reported [7]. MilRNAs are synthesized only in one species within a genus. For example, MILR1 is present only in Puccinia striiformis Westend but absent in Puccinia graminis Persoon and Puccinia triticina Erikss. Nevertheless, MILR1 is conserved across various $P$. striiformis strains. The formation of MILR1 in only one spe- 
cies may result from its evolution and adaptation to a specific host plant.

In plants, small RNAs can have several functions. They can be included in complexes, leading to mRNA degradation or initiate the synthesis of additional siRNAs [13]. Accordingly, a small RNA molecule can be either primary (formed through Dicer-mediated processing of a large dsRNA molecule) or secondary (synthesized through an RNA-dependent RNA polymerase). Both RNA types are subsequently involved in RNA interference [14].

Small RNAs are very mobile and can move throughout the body [15-17]. In plants, they move along the phloem from regions of high concentration to regions of low concentration [18]. RNAs are usually absent in the xylem, where water and ions move [19].

RNA movement between species belonging to different kingdoms (cross-kingdom RNA interference) has been described. This exchange of small RNAs (RNA trafficking) has been described in many interacting organisms, including plants, fungi, insects, bacteria, and symbionts. Moreover, the exchange of small RNAs is bidirectional [20, 21]. Pathogens and pests direct small RNAs to host cells to suppress host immunity; in turn, plants release small RNAs, which directly or indirectly inhibit pathogenic virulence [22-28]. The discovery of this phenomenon led to the term transacting siRNAs (tasiRNA). TasiRNAs do not always correspond with the target sequence; one tasiRNA species can suppress the expression of several genes [29].

Since small RNAs are transferred bidirectionally between host and pathogens, it is hypothesized that this phenomenon has an evolutionary significance in the development of "relationships" between species, thereby one organisms expand the range of biological units affected and, at the same time, other organisms can resist more pathogens and pests.
Many tasiRNAs are similar in size (20-25 bp) and structure. The $5^{\prime}$ end of tasiRNAs contains an uridine, which is important for the functioning of pathogenic small RNAs against plant hosts [30-35]. Uridine was reported to be involved in binding small RNAs to a specific protein of the Argonaute family, AGO1 [36].

Baldrich et al. [37] described another type of small RNA, 10-17 bp in size, called tiny RNA (tyRNA). TyRNA is possibly a degradation product of various RNA molecules, such as primary miRNA, siRNA, and tasiRNA. However, tyRNA can also function as a small activating RNA ( saRNA), which induces transcription [38].

\section{POSSIBLE WAYS OF SMALL RNA EXCHANGE BETWEEN ORGANISIMS}

An important question that arises in the study of RNA exchange between species includes the mechanism of "communication." At first, this was explained through physical laws, namely concentration-dependent diffusion. Later, a more complex selective process was believed to occur.

MiRNA is transferred between animal cells through exosomes, which are a type of extracellular vesicles [39, 40]. In animals, extracellular vesicles are categorized as exosomes, microvesicles (ectosomes), and apoptotic bodies according to specific protein markers and sites of formation [41]. In animals, small RNAs can also be transported through transmembrane proteins, high-density lipoprotein complexes, or gap junctions [42]. For example, the gastrointestinal parasite Heligmosomoides polygyrus synthesizes exosomes for transferring miRNAs to mammalian cells to reduce their immunity [25].

In plants, small RNAs seem to move between cells through plasmodesmata (intracellular bridges) and circulate through the vascular system [15, 43]. However, it was recently discovered that vesicles synthesized in plants are involved in the delivery of RNA to cells of other organisms. 
For example, fungal cells can efficiently absorb plant exosomes. Most likely, these exosomes protect small RNAs from nuclease attack, which explains their stability and activity after transfer $[8,21]$.

Arabidopsis thaliana (L.) Heynh secretes exosomes containing small RNAs to suppress the expression of virulence genes in some fungi. Into the hypha of the fungus Verticillium dahliae Kleb., cotton plants export MIR166 and MIR159, which negatively affect the expression of $\mathrm{Ca}^{2+}$-dependent cysteine protease $(C l p-1)$ and isotrihoderminC-15-hydroxylase (HiC-15). Both genes play a significant role in fungal virulence [28]. In some fungi, such as Fusarium graminearum (Schwein.) Petch, hyphae play a major role in RNA transfer [17]. Notably, small RNAs of transgenic organisms are also delivered to fungal cells through extracellular vesicles [26].

Cai et al. [43] reported that $A$. thaliana cells transport small RNAs to Botrytis cinerea Persoon through extracellular vesicles. The transfer of small RNAs to fungal cells led to the suppression of virulence genes resulting in high concentrations of transmembrane proteins (tetraspanins, TET8-CFP and TET9-YFP) and a positive effect on plant immunity.

Feng et al. [44] analyzed miRNAs synthesized in wheat during $P$. striformis infection and isolated genes targeted by miRNAs. These genes encoded proteins with the RabGAP/TBC domain, the zinc finger protein, and the cysteine-rich receptor-like protein kinase-41, which may play an important role in the interaction of wheat resistance genes with avirulence genes in $P$. striiformis.

Intergeneric RNA exchange was also reported in humans during miRNA delivery to Plasmodium falciparum Welch, which suppress the virulence genes of the parasite. This explains why patients with sickle cell disease, having an increased level of transported miRNAs, become more resistant to malaria [45].

\section{SMALL RNA AS A TOOL IN THE ATTACK OF PATHOGENS}

Pathogenic microorganisms and pests have evolved mechanisms to reduce host resistance. One of these mechanisms includes the synthesis of effector proteins, which target specific molecular structures of the host [46-48]. In addition to proteins, small RNA molecule can have similar functions [36]. RNA effectors mostly suppress genes that are key elements of the host's innate immune system. They either reduce the expression of homologous genes, eliminating functional redundancy, or directly or indirectly target the efficiency of the immune response [23].

Infection with $B$. cinerea decreases the synthesis of mitogen-activated protein kinase 1 (MPK1) and MPK2, peroxiredoxin-2F (PRXIIF), and cell wall-associated kinase in A. thaliana. In tomato, the biosynthesis of mitogen-activated protein kinase kinase kinase 4 (MAPKKK4), a kinase of the MAP-kinase cascade, which affects plant resistance to B. cinerea, was inhibited [24].

Pathogens use the plant's silencing system to gain advantage during colonization. During the isolation and precipitation of Argonaute (AGO1, Argonaute RISC Component 1), which is a component of post-transcriptional gene silencing, small RNAs of the pathogen (associated with plant AGO1) were found in the protein fraction isolated from the leaf of infected A. thaliana [24].

When studying the causative agents of powdery mildew, Kusch et al. [11] analyzed several small RNAs secreted by the fungus at the time of infection. Nucleotide sequences of these RNAs were complementary to a large number of plant genes, which indicates their multifunctionality. Most genes were found to be involved in acyl-CoA transport, ubiquinone biosynthesis, seed germination in wheat, and macromolecular catabolism in barley [1 11 .

Derbyshire et al. [36] reported that the fungus Sclerotinia sclerotiorum (Lib.) De Bary, 
which infects a large number of agricultural crops, produces small RNAs in high concentrations to suppress plant immune signaling. At the same time, target genes change depending on the host plant.

Feng et al. [44] found that small RNAs of the fungus Blumeria graminis Speer affect signal transmission and energy exchange in wheat cells, which may be associated with nutrient absorption from the host or suppression of apoptosis. Thus far, no targets of small RNAs involved in the immune response of wheat have been identified [44].

Derbyshire et al. reported that almost all loci of small RNAs of $S$. sclerotiorum were associated with retrotransposons. Similar to sequences of effector genes, they were present outside encoding regions; however, regions including these loci were more polymorphic, which indicates a rapidly evolving set of small RNA effectors associated with mobile elements of the genome. This polymorphism indicates that these regions represent an important component of evolution in the adaptation of the pathogen to a wide range of host plants. The random effect of small RNAs on host immunity possibly provides the pathogen a selective advantage. Small RNAs that have a significant effect on the infection process are called ribonucleic effectors [36].

During their studies on diseases of wheat, Wang et al. [8] found that miRNA-like RNA (milRNA), which is synthesized by $P$. striiformis, could suppress the plant's defense. This RNA takes part in "cross-kingdom" RNA interference by affecting the expression of the $\beta$-1,3-glucanase gene (PR2) in wheat. The suppression of the synthesis of the milRNA precursor led to an increase in wheat resistance to the virulent $P$. striiformis strain, and a decrease in $P R 2$ expression led to an increase in plant sensitivity to the avirulent pathogenic strain. Thus, this RNA is an important factor in fungal virulence [8].
When a plant is colonized by fungi, its immune system triggers a chain of protective reactions. Such reactions are induced by pathogen-associated molecular patterns, which include the synthesis of antimicrobial compounds. These compounds include pathogenesis-related proteins, such as proteinases, chitinases, and glucanases, which damage the structure of the pathogen [49].

In response, pathogens direct effectors into host cells to suppress PAMP-triggered immunity. This initiates effector-triggered immunity in plants, which is the second inducible level of protection. Small RNAs of pathogens can have a significant effect on effector-activated plant resistance. They can indirectly enhance pathogenic virulence by regulating the expression level of effectors. For example, small RNAs regulate the synthesis of avirulence conferring enzyme 1 (ACE1), which is an effector in Magnaporthe oryzae Couch and regulates the penetration of apressoria into plant tissue [50, 51]. Qutob et al. [52] reported that some pathogens can synthesize small RNAs to evade host defense.

\section{SMALL RNA IMMUNE RESPONSE OF PLANTS TO INFECTION}

Zhang et al. [28] described a new conservation strategy for protecting plants against fungi and oomycetes using small RNAs aimed at suppressing the expression of virulence genes. They isolated a common pool of small RNAs from $V$. dahliainfected cotton and performed deep sequencing. A large number of small RNAs did not associate with the pathogen's genome. However, approximately 28 small RNAs were identical to the genome of cotton. Northern blotting results revealed that these small RNAs were absent in the fungal material obtained in the system in vitro. Therefore, without preliminary cultivation of the fungus on the plant, the appearance of these molecules in the fungus is impossible. However, a large amount 
of the studied small RNAs were found in the roots of cotton and $A$. thaliana after fungal infection. Thus, high concentrations of small RNAs of plant origin were transferred to fungal hyphae after infection. Later, it was revealed that most small RNAs exported from cotton plants acted on the virulence genes of $V$. dahliae, thereby promoting fungal resistance [28].

More than 200 new miRNA families were identified in Triticum aestivum L., Aegilops sharonensis Eig, Aegilops speltoides Tausch, Aegilops tauschii Coss., Triticum monococcum L., and Triticum urartu Thumanjan ex Gandilyan genomes [53].

Dutta et al. [29] described a new tasiRNA producing locus (TAS) in wheat, when the plant is infected with stem rust. This locus can generate four types of small RNAs, which in turn act on $\alpha$-gliadin, leucine-rich repeat (LRR), transmembrane proteins, glutathione S-transferase (GST), and fatty acid desaturase, synthesized during stress and required for normal plant growth and development. Furthermore, $\alpha$-gliadin affects germination and seedling growth in wheat; its absence causes a noticeable deterioration in the quality of the protein $[29,54]$.

The LRR domain, present in plant cell membrane kinases, can recognize and bind to pathogenic effectors. Reportedly, plants need to get rid of excess LRRs under biotic stress [55].

Transmembrane proteins are involved in the transfer of molecules between adjacent cells. They are influenced by various external stimuli, in response to which they activate a cascade of reactions. Moreover, transmembrane proteins can act as a sensitivity factor in infection; therefore, suppression of their expression enhances plant resistance [56].

Plant responses to stress factors are associated with the formation of reactive oxygen species (ROS) [57], which are involved in several cellular processes and induce cell death [58].
Glutathione-S-transferase forms chelates of reactive oxygen species (organic peroxides) and controls necrosis by suppressing oxidative tissue damage [59], and siRNA-mediated knockdown of GST expression leads to necrosis of infected tissues and limits the spread of infection.

Fatty acid desaturases convert saturated fatty acids into unsaturated ones, which affect membrane mobility, and ultimately, signal transduction between cells [60]; by contrast, ROS increase the intensity of signals controlled by them.

Canto-Pastor et al. [13] reported that the miRNA family reduces the expression of nucleotide binding site leucine-rich repeat (NLR) proteins. Small RNAs of the miR482/2118 family have several functions. They are involved in the cleavage of mRNA and activate the secondary synthesis of siRNAs, using the target RNA as a template.

MiR482 acts on the conserved motif of various mRNAs of NLR proteins, whereas miR2118b acts on noncoding RNA formed by the rearrangement of several different NLR genes. Tomato lines that synthesize short tandem target mimic (STTM) RNAs, which affect various genes, demonstrate increased resistance to infection against oomycetes and bacteria. In this case, NLR proteins are involved in the formation of quantitative resistance. Canto-Pastor et al. [13] also provided information on the use of STTM-RNA in biotechnology to enhance the quantitative resistance of some varieties.

\section{HOST-INDUCED GENE SILENCING (HIGS)}

When studying the host-pathogen interaction, host-induced gene silencing (HIGS) is widely used, which is based on creating transgenic plants capable of independently secreting target dsRNA to suppress the expression of pathogenic genes.

HIGS has been effectively used in plants infected by nematodes [61], insects [62, 63], fungi [5, 26, 64], and oomycetes [65, 66]. HIGS can easily be adapted for the simultaneous control of 
several pathogens by suppressing the expression of important virulence genes [26]. Nevertheless, one of the limitations of using HIGS is the successful genetic transformation of plants, which is not yet possible for many economically important crops. In addition, concerns remain about the consumption of genetically modified plants [21], the cultivation of which is prohibited in Russia and other countries.

It should be said that the HIGS mechanism, although controlled by humans, is an excellent example of small RNA transfer from hosts to pathogenic microorganisms or pests [8, 61-64, 67].

Virus-induced gene silencing (VIGS) is a variation of HIGS, in which the synthesis of double-stranded molecules in plants is performed transiently by the virus, which functions as an additional factor, leading to the formation of target dsRNAs. This enables avoiding the need for genetic transformation and assesses pathogenic virulence by suppressing the expression of virulence genes. This technology has been used for several decades and has enabled advances in the study of genetic interactions of many pathosystems. First, the plant is infected with a viral construct containing the target sequence to enable the formation of double-stranded molecules. When the infection is effective and a stable synthesis of dsRNA is registered, the next stage is implemented, namely, infection with the studied pathogen or pest. The efficiency of VIGS varies among plants, and the interaction of three biological units (plant, virus, and the investigated pathogen) can lead to ambiguous results [68]. It should be remembered that even a modified virus will be a stress factor for the plant, which will lead to the emergence of specific protective reactions even before infection with the corresponding pathogen. Such a plant will undoubtedly be different from a healthy plant that is not infected by the virus. Under stress, the plant's immunity functions at full strength and in case of colonization with the second pathogen, the result of such an interaction may be ambiguous. The use of this technology in the field is economically inexpedient; in addition, there is a danger of the genetically modified virus being released into the environment.

Many obligate parasitic microorganisms absorb host nutrients through specialized organs called haustoria and hyphae. Zhu et al. [69] studied the development of the stripe rust pathogen $P$. striiformis var. tritici on wheat (T. aestivum). Mitogen-activated protein kinase kinase is encoded by PSFUZ7 and regulates haustorium formation and invasive growth. PSKPP4, homologous to STE11 (MAPKKK), has also been characterized in yeast. As in the case of PSFUZ7 silencing, a decrease in PSKPP4 expression in hyphae and haustoria was analyzed leading to a decrease in fungal aggressiveness. P. striiformis urediniospores treated with an inhibitor of STE1 1 formed deformed germ tubes. Increased expression of PSKPP4 in yeast during cell division led to the synthesis of fusiform cells and increased resistance to oxidative stress [69].

Koch et al. [5] reduced the expression of CYP51, which is required for ergosterol biosynthesis, and evaluated the effect of silencing on the growth of $F$. graminearum. When dsRNA, complementary to CYP51, was introduced into a liquid culture of $F$. graminearum, suppression of fungal growth and change in its morphological parameters were noted. These effects were similar to those of the fungicide tebuconazole. The creation of transgenic lines of $A$. thaliana and barley expressing dsRNAs led to a significant increase in the resistance of typically-sensitive genotypes. Mycelium growth was limited at the sites of pathogen inoculation, and inoculated barley kernels were free of fungal hyphae. The suppression of fungal growth had a positive correlation with the synthesis of small RNAs and the efficiency of CYP51 silencing [5].

Cheng et al. [70] determined that the suppression of chitin synthase gene of $F$. graminearum 
increased the resistance of transgenic wheat plants. This enzyme is vital for fungus. Expression of three RNA constructs in two different transgenic wheat cultivars ensured a high resistance of the culture to Fusarium head blight and fungal development on T3-T5 seedlings. Growth restriction of the pathogen was also confirmed by confocal microscopy.

\section{SPRAY-INDUCED GENE SILENCING IN PLANT PROTECTION: VALUE AND PROSPECTS}

In 2016, a new system for artificially inducing RNA interference, called spray-induced gene silencing (SIGS), was proposed. It involves introducing dsRNA into a liquid nutrient medium with microorganisms or spraying it over the surface of a solid object, such as a leaf [17]. This discovery provided a new strategy for crop protection and pesticide replacement.

DsRNA sprayed onto leaves first reaches the apoplast, xylem, and then moves to the symplast. Acropetal movement of the silencing signal revealed inhibition of fungal growth in areas where dsRNA did not reach, which indicates the high efficiency of double-stranded molecules [17].

The use of dsRNA has many advantages over chemicals. DsRNA-based agents can act specifically against certain pathogen that has a homologous sequence in the genome. As pathogens evolve and become resistant to dsRNA, the use of a mixture of different dsRNA molecules would be a possible solution to target different regions of a gene or several genes. The development of such agents should be performed considering the beneficial microflora since there can be homologous sequences in their genomes, especially for "house-keeping" genes. The use of dsRNA based on such sequences can lead to a nonspecific inhibitory effect on soil microorganisms and symbionts [17].

The environmental friendliness of such agents should also be noted. Unlike chemicals, dsRNA is a natural component prone to degradation [71]. In plants and animals, dsRNA passes through a chain of reactions leading to its cleavage into shorter molecules, which subsequently also undergo natural degradation [72]. This suggests that spraying dsRNA will not lead to the formation of new residual compounds in food [71].

The use of dsRNA in plant protection requires deep research. Studies on calculating and optimizing the cost of dsRNA production and improving its stability are warranted. Therefore, studies on developing low-cost systems that stably synthesize good quality dsRNA are needed [71].

The main method for synthesizing dsRNA includes hybridization of sense and antisense RNA strands using enzymes into a double-stranded molecule. Hybridization of strands is performed either in vitro [17,26,73-75] or in vivo after the synthesis of single-stranded RNA (ssRNA) in bacterial cells in the absence of RNase III [76-78]. The physical hybridization of two complementary strands in vitro, and especially in vivo, leads often to a low concentration of correctly synthesized double-stranded molecules. In addition, bacterial systems contain homologous DNA molecules, which affect the quality and efficiency of the final RNA molecules.

Niehl et al. [79] reported that synthesis of dsRNA using enzymes isolated from viruses capable of producing double-stranded molecules naturally is the most efficient method. They developed a dsRNA-replication system in the bacterium Pseudomonas syringae Van Hall using bacteriophage phi6 components, which allow for the synthesis of large, high quality RNA molecules in large quantities. Stability of dsRNA synthesis was achieved by combining three distinct segments of the bacteriophage genome in a vector, maintaining the natural size of the dsRNA, and the elements required for efficient replication and packaging of the segments. Such a system can be easily adapted for the synthesis of various target sequences [79]. 
The synthesis of large dsRNA molecules (>2600 bp) can help obtain a large pool of small RNAs. The technology was developed to increase the stability of dsRNA after spraying for up to $20 \mathrm{~d}$ or more $[79,80]$.

\section{LIMITATIONS OF SIGS}

Due to its structure, dsRNA is more stable than single-stranded molecules, although its lifespan is limited by the presence of various RNases [81]. Singh et al. [82] demonstrated that the rate of dsRNA cleavage and processing varied significantly among insect species. Song et al. [71] suggested that dsRNA remains stable for only $8 \mathrm{~d}$ after being sprayed on plants.

When developing plant protection measures against a particular pathogen, it is necessary to ensure that this organism is capable of RNA interference. The absence of components of RNA interference in some pathogens makes this method ineffective.

When synthesizing dsRNA, the effects of offtarget silencing must be considered, when the resulting small RNA is complementary or partially complementary to one or more mRNAs that are not the target of silencing [83, 84].

Koch et al. [17] used dsRNA spraying in the $F$. graminearum-barley system. They reported that spraying dsRNA, which targeted three CYP51 paralog genes, resulted in decreased fungal growth. The dsRNA moving through the plant's vascular system was absorbed by the fungus through the leaf. The movement of small RNAs along the plant's vascular system is a very slow and inefficient process. Therefore, when developing special agents, the use of large molecules may be a better choice [17].

Song et al. [71] used SIGS to suppress the expression of myosin-5 (MYO5) in the fungus Fusarium asiaticum O’Donnell, Aoki, Kistler, Geiser. The dsRNA molecules complementary to several regions of the target gene led to the appearance of cell wall defects, directly affecting mycelium growth and fungal virulence. To determine the duration of $\mathrm{RNA}$ interference, the growth rate of the fungal mycelium was estimated after removal of dsRNA from the nutrient medium. During the first $5 \mathrm{~h}$ after the removal of dsRNA, the growth rate of the fungal mycelium was comparable to that on a medium constantly supplied with dsRNA, which indicates an effective suppression of MYO5 expression. Between 5 and $9 \mathrm{~h}$, the growth rate of the mycelium increased gradually, and after 9 h it was comparable to the control. Because $F$. asiaticum is unable to maintain the synthesis of secondary small RNAs, target gene expression was restored after all exogenous dsRNA molecules were used in RNA interference. With a constant supply of dsRNAs in the nutrient medium, inhibition of MYO5 expression could last $7 \mathrm{~d}$ [71].

RNA molecules on the surface of plants are stable for approximately one week, which in some cases is insufficient to control pathogens [71]. However, in contrast to fungi, siRNAs can be reamplified in plant, and thus, propagated [85]. The concentration of secondary small RNAs is much higher than that of primary ones, and they can significantly reduce the expression level of the corresponding gene [86]. Thus, the anti-fungal activity of dsRNA was higher and lasted longer when it first entered plants and after that into the fungus, compared to the effect of molecules on the surface of organs of wheat. In this case, dsRNAs most efficiently penetrate into the plant through damage [71].

Furthermore, dsRNA molecules complementary to different regions of the same gene can have different effects on biological processes. After spraying, dsRNA either dries on the plant surface or is absorbed by plant cells. When a plant is infected by a fungus, the dsRNA on the surface cannot be transferred to the infected site by means of vascular tissue and is absorbed by fungal cells only if the pathogen enters the area where the molecules 
have been sprayed; however, the effect does not last long, because the fungus is unable to amplify small RNAs [71].

The SIGS method has also been used to control insect pests. Application of the corresponding dsRNAs on plants significantly increased mortality and impaired insect growth [87-90]. This effect can be achieved when molecules enter both the top parts and roots of plants [21].

A recent study revealed that dsRNA stability increased for up to $20 \mathrm{~d}$ when sprayed onto BioClay nanosheets [80]. These particles reduce the rate of RNase-mediated degradation of dsRNAs under the influence of sunlight and prevented its rapid washing off from the leaf surface. Because nanoparticles have no toxic effects and are easily degraded, this method is environmentally friendly and can be applied in the field to control various plant diseases [21]

\section{CONCLUSIONS}

RNA interference has proven to be an effective means of studying interactions between several organisms and a tool for developing new plant protection measures. Several types of small RNAs and their exchange between different species have been discovered and described. Such communication has evolved among species during competition for food sources, and apparently, exists between many interacting organisms. Small RNAs represent a natural component of the cell and participates in maintaining its vital functions. Some small RNAs of pathogens are called ribonucleic effectors, because they act against the host's immunity. The use of HIGS and VIGS has advanced the understanding of resistance development in some organisms and virulence in others. The new SIGS system is of particular importance, as its efficiency can surpass the action of many pesticides.

\section{REFERENCES}

1. Kim VN, Han J, Siomi MC. Biogenesis of small RNAs in animals. Nat Rev Mol Cell Biol.
2009;10(2):126-139. https://doi.org/10.1038/ nrm2632.

2. Baulcombe D. RNA silencing in plants. $\mathrm{Na}$ ture. 2004;431(7006):356-363. https://doi.org/ 10.1038 /nature02874.

3. Vaucheret H, Vazquez F, Crété P, et al. The action of Argonautel in the miRNA pathway and its regulation by the miRNA pathway are crucial for plant development. Genes Dev. 2004;18(10): 1187-1197. https://doi.org/10.1101/gad. 1201404 .

4. Brodersen P, Voinnet O. The diversity of RNA silencing pathways in plants. Trends Genet. 2006;22(5):268-280. https://doi.org/10.1016/j. tig.2006.03.003.

5. Koch A, Kumar N, Weber L, et al. Host-induced gene silencing of cytochrome P450 lanosterol C14 $\alpha$-demethylase-encoding genes confers strong resistance to Fusarium species. Proc Natl Acad Sci USA. 2013;110(48):19324-19329. https:// doi.org/10.1073/pnas.1306373110.

6. Lee HC, Li L, Gu W, et al. Diverse pathways generate microRNA-like RNAs and Dicer-independent small interfering RNAs in fungi. Mol Cell. 2010;38(6):803-814. https://doi.org/10.1016/j. molcel.2010.04.005.

7. Weiberg A, Wang M, Bellinger $M$, et al. Small RNAs: a new paradigm in plant-microbe interactions. Annu Rev Phytopathol. 2014;52: 495-516. https://doi.org/10.1146/annurev-phyto-102313-045933.

8. Wang B, Sun Y, Song N, et al. Puccinia striiformis f. sp. tritici microRNA-like RNA 1 (PstmilR1), an important pathogenicity factor of Pst, impairs wheat resistance to Pst by suppressing the wheat pathogenesis-related 2 gene. New Phytol. 2017;215(1):338-350. https://doi.org/10.1111/ nph. 14577.

9. Cerutti H, Casas-Mollano JA. On the origin and functions of RNA-mediated silencing: from protists to man. Curr Genet. 2006;50(2):81-99. https://doi.org/10.1007/s00294-006-0078-x.

10. Laurie JD, Linning R, Bakkeren G. Hallmarks of RNA silencing are found in the smut fungus Ustilago hordei but not in its close relative Ustilago maydis. Curr Genet. 2008;53(1): 49-58. https://doi.org/10.1007/s00294-007 0165-7. 
11. Kusch S, Frantzeskakis L, Thieron H, et al. Small RNAs from cereal powdery mildew pathogens may target host plant genes. Fungal Biol. 2018;122(11):1050-1063. https://doi.org/ 10.1016/j.funbio.2018.08.008.

12. Nicolás FE, Garre V. RNA interference in fungi: retention and loss. Microbiol Spectr. 2016;4(6). https://doi.org/10.1128/microbiolspec.funk-0008-2016.

13. Canto-Pastor A, Santos BA, Valli AA, et al. Enhanced resistance to bacterial and oomycete pathogens by short tandem target mimic RNAs in tomato. Proc Natl Acad Sci USA. 2019;116(7):2755-2760. https://doi.org/10. 1073/pnas. 1814380116.

14. Pak J, Fire A. Distinct populations of primary and secondary effectors during RNAi in C. elegans. Science. 2007;315(5809):241-244. https://doi. org/10.1126/science. 1132839 .

15. Molnar A, Melnyk CW, Bassett A, et al. Small silencing RNAs in plants are mobile and direct epigenetic modification in recipient cells. Science. 2010;328(5980):872-875. https://doi. org/10.1126/science.1187959.

16. Lewsey MG, Hardcastle TJ, Melnyk CW, et al. Mobile small RNAs regulate genome-wide DNA methylation. Proc Natl Acad Sci USA. 2016;113(6):E801-E810. https://doi.org/10. 1073/pnas.1515072113.

17. Koch A, Biedenkopf D, Furch A, et al. An RNAiBased Control of Fusarium graminearum infections through spraying of long dsRNAs involves a plant passage and is controlled by the fungal silencing machinery. PLoS Pathog. 2016;12(10): e1005901. https://doi.org/10.1371/journal.ppat.1005901.

18. Ding B. The biology of viroid-host interactions. Annu Rev Phytopathol. 2009;47:105-131. https://doi.org/10.1146/annurev-phyto-080508081927.

19. Buhtz A, Springer F, Chappell L, et al. Identification and characterization of small RNAs from the phloem of Brassica napus. Plant J. 2008;53(5):739-749. https://doi.org/10.1111/ j.1365-313x.2007.03368.x.

20. Weiberg A, Jin H. Small RNAs - the secret agents in the plant-pathogen interactions. Curr Opin Plant Biol. 2015;26:87-94. https://doi. org/10.1016/j.pbi.2015.05.033.
21. Wang M, Thomas N, Jin H. Cross-kingdom RNA trafficking and environmental RNAi for powerful innovative pre- and post-harvest plant protection. Curr Opin Plant Biol. 2017;38:133-141. https://doi.org/10.1016/j.pbi.2017.05.003.

22. Weiberg A, Bellinger M, Jin H. Conversations between kingdoms: small RNAs. Curr Opin Biotechnol. 2015;32:207-215. https://doi. org/10.1016/j.copbio.2014.12.025.

23. Wang $M$, Weiberg A, Dellota E, et al. Botrytis small RNA Bc-siR37 suppresses plant defense genes by cross-kingdom RNAi. RNA Biol. 2017;14(4):421 -428. https://doi.org/10.1080/1 5476286.2017 .1291112 .

24. Weiberg A, Wang M, Lin FM, et al. Fungal small RNAs suppress plant immunity by hijacking host RNA interference pathways. Science. 2013;342(6154):118-123. https://doi. org/10.1126/science. 1239705.

25. Buck AH, Coakley G, Simbari F, et al. Exosomes secreted by nematode parasites transfer small RNAs to mammalian cells and modulate innate immunity. Nat Commun. 2014;5( 1):5488. https://doi.org/10.1038/ncomms6488.

26. Wang M, Weiberg A, Lin FM. Bidirectional cross-kingdom RNAi and fungal uptake of external RNAs confer plant protection. Nat Plants. 2016;2:16151. https://doi.org/10.1038/ nplants.2016.151.

27. Shahid S, Kim G, Johnson NR et al. MicroRNAs from the parasitic plant Cuscuta campestris target host messenger RNAs. $\mathrm{Na}$ ture. 2018;553(7686):82-85. https://doi.org/ 10.1038 /nature25027.

28. Zhang T, Zhao YL, Zhao JH, et al. Cotton plants export microRNAs to inhibit virulence gene expression in a fungal pathogen. Nat Plants. 2016;2:16153. https://doi.org/10.1038/ nplants.2016.153.

29. Dutta S, Kumar D, Jha S, et al. Identification and molecular characterization of a trans-acting small interfering RNA producing locus regulating leaf rust responsive gene expression in wheat (Triticum aestivum L.) Planta. 2017;246(5):939-957. https://doi.org/10.1007/s00425-017-2744-2.

30. Ghildiyal M, Xu J, Seitz H, et al. Sorting of Drosophila small silencing RNAs partitions microRNA strands into the RNA interference 
pathway. RNA. 2010;16(1):43-56. https://doi. org/10.1261/rna.1972910.

31. Mi S, Cai T, Hu Y, et al. Sorting of small RNAs into Arabidopsis Argonaute Complexes is directed by the 5 '-terminal nucleotide. Cell. 2008;133(1):116-127. https://doi. org/10.1016/j.cell.2008.02.034.

32. Mueth NA, Ramachandran SR, Hulbert SH. Small RNAs from the wheat stripe rust fungus (Puccinia striiformis f. sp. tritici). BMC Genomics. 2015;16(1):718. https://doi.org/10.1186/ s12864-015-1895-4.

33. Shapulatov UM, Buriev ZT, Ulloa $M$, et al. Characterization of small RNAs and their targets from Fusarium oxysporum infected and noninfected cotton root tissues. Plant Mol Biol Report. 2016;34(3):698-706. https://doi.org/10.1007/ s11105-015-0945-z.

34. Yang F. Genome-wide analysis of small RNAs in the wheat pathogenic fungus Zymoseptoria tritici. Fungal Biol. 2015;119(7):631-640. https://doi.org/10.1016/j.funbio.2015. 03.008 .

35. Vetukuri RR, Asman AKM, Tellgren-Roth C, et al. Evidence for small RNAs homologous to effector-encoding genes and transposable elements in the oomycete Phytophthora infestans. PLoS One. 2012;7(12):e51399. https://doi.org/ 10.1371/journal.pone.0051399.

36. Derbyshire $M$, Mbengue $M$, Barascud $M$, et al. Small RNAs from the plant pathogenic fungus Sclerotinia sclerotiorum highlight host candidate genes associated with quantitative disease resistance. Mol Plant Pathol. 2019;20(9): 1279 - 1297. https://doi.org/10.1111/mpp. 12841 .

37. Baldrich P, Rutter BD, Karimi HZ, et al. Plant extracellular vesicles contain diverse small RNA species and are enriched in 10- to 17 -nucleotide “tiny” RNAs. Plant Cell. 2019;31(2):315-324. https://doi.org/10.1105/tpc.18.00872.

38. Li LC, Okino ST, Zhao H, et al. Small dsRNAs induce transcriptional activation in human cells. Proc Natl Acad Sci USA. 2006;103(46):17337-17342. https://doi.org/10.1073/pnas.0607015103.

39. Valadi H, Ekström K, Bossios A, et al. Exosomemediated transfer of mRNAs and microRNAs is a novel mechanism of genetic exchange between cells. Nat Cell Biol. 2007:9(6):654-659. https:// doi.org/10.1038/ncb1596.

40. Mittelbrunn M, Gutiérrez-Vázquez C, VillarroyaBeltri C, et al. Unidirectional transfer of microRNAloaded exosomes from T-cells to antigen-presenting cells. Nat Commun. 2011;2(1):282. https:// doi.org/10.1038/ncomms 1285.

41. Colombo M, Raposo G, Théry C. Biogenesis, secretion, and intercellular interactions of exosomes and other extracellular vesicles. Annu Rev Cell Dev Biol. 2014:30(1): 255-289. https://doi.org/10.1146/annurevcellbio-101512-122326.

42. Mittelbrunn M, Sánchez-Madrid F. Intercellular communication: diverse structures for exchange of genetic information. Nat Rev Mol Cell Biol. 2012;13(5):328-335. https://doi.org/10.1038/ nrm3335.

43. Cai Q, Qiao L, Wang $M$, et al. Plants send small RNAs in extracellular vesicles to fungal pathogen to silence virulence genes. Science. 2018;360(6393):1126-1129. https://doi. org/10.1126/science.aar4142.

44. Feng H, Wang B, Zhang Q, et al. Exploration of microRNAs and their targets engaging in the resistance interaction between wheat and stripe rust. Front Plant Sci. 2015;6:469. https://doi. org/10.3389/fpls.2015.00469.

45. LaMonte G, Philip N, Reardon J, et al. Translocation of sickle cell erythrocyte microRNAs into Plasmodium falciparum inhibits parasite translation and contributes to malaria resistance. Cell Host Microbe. 2012;12(2):187-199. https://doi. org/10.1016/j.chom.2012.06.007.

46. Ashida H, Ogawa M, Kim M, et al. Shigella deploy multiple countermeasures against host innate immune responses. Curr Opin Microbiol. 2011;14(1):16-23. https://doi.org/10.1016/j. mib.2010.08.014.

47. Rafiqi M, Ellis JG, Ludowici VA, et al. Challenges and progress towards understanding the role of effectors in plant-fungal interactions. Curr Opin Plant Biol. 2012;15(4):477-482. https:// doi.org/10.1016/j.pbi.2012.05.003.

48. Bozkurt TO, Schornack S, Banfield MJ, et al. Oomycetes, effectors, and all that jazz. Curr Opin Plant Biol. 2012:15(4):483-492. https:// doi.org/10.1016/j.pbi.2012.03.008. 
49. Muthukrishnan S, Liang GH, Trick $\mathrm{HN}$, et al. Pathogenesis-related proteins and their genes in cereals. Plant Cell Tissue Organ Cult. 2001; 64:93-114.

50. Fudal I, Collemare J, Böhnert HU, et al. Expression of Magnaporthe grisea avirulence gene ACE1 is connected to the initiation of appressorium-mediated penetration. Eukaryot Cell. 2007;6(3):546-554. https://doi.org/10.1128/ ec.00330-05.

51. Raman V, Simon SA, Romag A, et al. Physiological stressors and invasive plant infections alter the small RNA transcriptome of the rice blast fungus, Magnaporthe oryzae. BMC Genomics. 2013;14(1):326. https://doi.org/10.1186/1471 2164-14-326.

52. Qutob D, Chapman BP, Gijzen M. Transgenerational gene silencing causes gain of virulence in a plant pathogen. Nat Commun. 2013;4(1):1349. https://doi.org/10.1038/ncomms2354.

53. Alptekin B, Budak H. Wheat miRNA ancestors: evident by transcriptome analysis of $\mathrm{A}$, $\mathrm{B}$, and D genome donors. Funct Integr Genomics. 2017;17(2-3):171-187. https://doi. org/10.1007/s10142-016-0487-y.

54. Van Herpen TW, Riley M, Sparks C, et al. Detailed analysis of the expression of an alphagliadin promoter and the deposition of alphagliadin protein during wheat grain development. Ann Bot. 2008;102(3):331-342. https://doi. org/10.1093/aob/men 114 .

55. Hohmann U, Lau K, Hothorn M. The structural basis of ligand perception and signal activation by receptor kinases. Annu Rev Plant Biol. 2017;68(1):109-137. https://doi.org/10.1146/ annurev-arplant-042916-040957.

56. Zheng Z, Appiano M, Pavan S, et al. Genomewide study of the tomato SIMLO gene family and its functional characterization in response to the powdery mildew fungus Oidium neolycopersici. Front Plant Sci. 2016;7:380. https://doi. org/10.3389/fpls.2016.00380.

57. Chojak-Koźniewska J, Linkiewicz A, Sowa S, et al. Interactive effects of salt stress and Pseudomonas syringae pv. lachrymans infection in cucumber: involvement of antioxidant enzymes, abscisic acid and salicylic acid. Environ Exp Bot. 2017;136:9-20. https://doi.org/10.1016/j.envexpbot.2017.01.004.
58. Mittler R. ROS are good. Trends Plant Sci. 2017;22(1):11 - 19. https://doi.org/10.1016/j. tplants.2016.08.002.

59. Dalton DA, Boniface C, Turner $Z$, et al. Physiological roles of glutathione-S-transferases in soybean root nodules. Plant Physiol. 2009;150(1):521-530. https://doi. org/10.1104/pp.109.136630.

60. Menard GN, Moreno JM, Bryant FM, et al. Genome wide analysis of fatty acid desaturation and its response to temperature. Plant Physiol. 2017;173(3):1594-1605. https://doi. org/10.1104/pp.16.01907.

61. Huang G, Allen R, Davis EL, et al. Engineering broad root-knot resistance in transgenic plants by RNAi silencing of a conserved and essential root-knot nematode parasitism gene. Proc Natl Acad Sci USA. 2006;103(39):14302-14306. https://doi.org/10.1073/pnas.0604698103.

62. Mao YB, Cai WJ, Wang JW, et al. Silencing a cotton bollworm P450 monooxygenase gene by plantmediated RNAi impairs larval tolerance of gossypol. Nat Biotechnol. 2007;25(11):1307-1313. https://doi.org/10.1038/nbt1352.

63. Baum JA, Bogaert T, Clinton W, et al. Control of coleopteran insect pests through RNA interference. Nat Biotechnol. 2007;25(11):1322-1326. https://doi.org/10.1038/nbt1359.

64. Nowara D, Gay A, Lacomme C, et al. HIGS: host-induced gene silencing in the obligate biotrophic fungal pathogen Blumeria graminis. Plant Cell. 2010;22(9):3130-3141. https://doi. org/10.1105/tpc. 110.077040 .

65. Vega-Arreguin JC, Jalloh A, Bos JI, et al. Recognition of an Avr3a homologue plays a major role in mediating nonhost resistance to Phytophthora capsici in Nicotiana species. Mol Plant Microbe Interact. 2014;27(8):770-780. https://doi. org/10.1094/mpmi-01-14-0014-r.

66. Jahan SN, Asman AK, Corcoran P, et al. Plantmediated gene silencing restricts growth of the potato late blight pathogen Phytophthora infestans. J Exp Bot. 2015;66(9):2785-2794. https:// doi.org/10.1093/jxb/erv094.

67. Nunes CC, Dean RA. Host-induced gene silencing: a tool for understanding fungal host interaction and for developing novel disease control strategies. Mol Plant Pathol. 2012;13(5): 
519-529. https://doi.org/10.1111/j.1364-3703. 2011.00766.x.

68. Lee WS, Hammond-Kosack KE, Kanyuka K. Barley stripe mosaic virus-mediated tools for investigating gene function in cereal plants and their pathogens: virus-induced gene silencing, host-mediated gene silencing, and virus-mediated overexpression of heterologous protein. Plant Physiol. 2012;160(2):582-590. https:// doi.org/10.1104/pp.112.203489.

69. Zhu X, Guo J, He F, et al. Silencing PsKPP4, a MAP kinase kinase kinase gene, reduces pathogenicity of the stripe rust fungus. Mol Plant Pathol. 2018;19(12):2590-2602. https://doi. org/10.1111/mpp.12731.

70. Cheng W, Song XS, Li HP, et al. Host-induced gene silencing of an essential chitin synthase gene confers durable resistance to Fusarium head blight and seedling blight in wheat. Plant Biotechnol J. 2015;13(9):1335-1345. https:// doi.org/10.1111/pbi.12352.

71. Song XS, Gu KX, Duan XX, et al. Secondary amplification of siRNA machinery limits the application of spray-induced gene silencing. Mol Plant Pathol. 2018;19(12):2543-2560. https:// doi.org/10.1111/mpp.12728.

72. Cerutti H, Ibrahim F. Turnover of Mature miRNAs and siRNAs in Plants and Algae. Adv Exp Med Biol. 2011;700:124-139. https://doi. org/10.1007/978-1-4419-7823-3_11.

73. Carbonell A, Martínez de Alba Á-E, Flores R, et al. Double-stranded RNA interferes in a sequence-specific manner with the infection of representative members of the two viroid families. Virology. 2008;371(1):44-53. https://doi. org/10.1016/j.virol.2007.09.031.

74. Konakalla NC, Kaldis A, Berbati M, et al. Exogenous application of double-stranded RNA molecules from TMV p126 and CP genes confers resistance against TMV in tobacco. Planta. 2016;244(4):961-969. https://doi.org/10.1007/ s00425-016-2567-6.

75. Tenllado F, Díaz-Ruíz JR. Double-stranded RNAmediated interference with plant virus infection. J Virol. 2001;75(24):12288-12297. https://doi. org/10.1128/jvi.75.24.12288-12297.2001.

76. Gan D, Zhang J, Jiang H, et al. Bacterially expressed dsRNA protects maize against SCMV in- fection. Plant Cell Rep. 2010;29(11):1261-1268. https://doi.org/10.1007/s00299-010-0911-z.

77. Tenllado F, Barajas D, Vargas M, et al. Transient expression of homologous hairpin RNA causes interference with plant virus infection and is overcome by a virus encoded suppressor of gene silencing. Mol Plant Microbe Interact. 2003;16(2):149-158. https://doi.org/10.1094/ mpmi.2003.16.2.149.

78. Yin G, Sun Z, Liu N, et al. Production of double-stranded RNA for interference with TMV infection utilizing a bacterial prokaryotic expression system. Appl Microbiol Biotechnol. 2009;84(2):323-333. https://doi.org/10.1007/ s00253-009-1967-y.

79. Niehl A, Soininen M, Poranen MM, et al. Synthetic biology approach for plant protection using dsRNA. Plant Biotechnol J. 2018;16(9): 1679-1687. https://doi.org/10.1111/pbi.12904.

80. Mitter N, Worrall EA, Robinson KE, et al. Clay nanosheets for topical delivery of RNAi for sustained protection against plant viruses. Nat Plants. 2017;3:16207. https://doi.org/10.1038/ nplants.2016.207.

81. Dubelman S, Fischer J, Zapata F, et al. Environmental fate of double-stranded RNA in agricultural soils. PLoS One. 2014;9(3):e93155. https://doi.org/10.1371/journal.pone.0093155.

82. Singh IK, Singh S, Mogilicherla K, et al. Comparative analysis of double-stranded RNA degradation and processing in insects. Sci Rep. 2017;7(1):17059. https://doi.org/10.1038/s41598-017-17134-2.

83. Schussler MD, Alexandersson E, Bienert GP, et al. The effects of the loss of TIP1;1 and TIP $1 ; 2$ aquaporins in Arabidopsis thaliana. Plant $J$. 2008;56(5):756-767. https://doi.org/10.1111/ j. 1365-313X.2008.03632.x.

84. De Souza N. Off-targets in RNAi screens. Nat Methods. 2014;11(5):480. https://doi.org/ 10.1038/nmeth.2958.

85. Tang G, Reinhart BJ, Bartel DP, et al. A biochemical framework for RNA silencing in plants. Genes Dev. 2003;17(1):49-63. https://doi. org/10.1101/gad.1048103.

86. Zhang C, Ruvkun G. New insights into siRNA amplification and RNAi. RNA Biol. 2012;9(8): 1045-1049. https://doi.org/10.4161/rna. 21246. 
87. Pridgeon JW, Zhao LM, Becnel JJ, et al. Topically applied AaeIAP1 double-stranded RNA kills female adults of Aedes aegypti. J Med Entomol. 2008;45(3):414-420. https://doi.org/10.1603/ 0022-2585(2008)45[414: taadrk]2.0.co;2.

88. Wang YB, Zhang H, Li H, et al. Second-generation sequencing supplies an effective way to screen RNAi targets in large scale for potential application in pest insect control. PLoS One. 2011;6(4): e18644. https://doi.org/10.1371/journal.pone.0018644.
89. Killiny N, Hajeri S, Tiwari S, et al. Doublestranded RNA uptake through topical application, mediates silencing of five CYP4 genes and suppresses insecticide resistance in diaphorina citri. PLoS One. 2014;9(10): e110536. https:// doi.org/10.1371/journal.pone.0110536.

90. Miguel SK, Scott JG. The next generation of insecticides: dsRNA is stable as a foliar-applied insecticide. Pest Manag Sci. 2016;72(4):801-809. https://doi.org/10.1002/ps.4056.
Authors and affiliations

Polina Ya. Tretiakova - PhD student, department of Genetics, Plant Breeding and Seed Production. Russian State Agrarian University - Moscow Timiryazev Agricultural Academy, Moscow, Russia. SPIN: 8930-8251. E-mail: polina.tretiakova@yandex.ru.

Aleksandr A. Soloviev - Doctor of Science, Head of the Laboratory of Marker-Assisted and Genomic Selection of Plants. All-Russia Research Institute of Agricultural Biotechnology, Moscow, Russia. SPIN: 3431-5168. E-mail: a.soloviev70@gmail.com.

\section{\& Информация об авторах}

Полина Яковлевна Третьякова - аспирант, кафедра генетики, селекции и семеноводства. ФГБОУ ВО «Российский государственный аграрный университет - MCXА им. К.А. Тимирязева», Москва. SPIN: 8930-8251. E-mail: polina.tretiakova@ yandex.ru

Александр Александрович Соловьев - д-р биол. наук, заведующий лабораторией маркерной и геномной селекции растений. ФГБНУ «ВНИИ сельскохозяйственной биотехнологии», Москва. SPIN: 3431-5168. E-mail: a.soloviev70@gmail.com. 